\title{
Identification and evaluation of SND in a full-scale multi-channel oxidation ditch system under different aeration modes
}

\author{
Xin Zhou ${ }^{\mathrm{a}, \mathrm{b}, *}$, Yunping $\operatorname{Han}^{\mathrm{c}}$, Xuesong Guo ${ }^{\mathrm{c}}$ \\ ${ }^{a}$ College of Environmental Science and Engineering, Taiyuan University of Technology, Taiyuan 030024, China \\ ${ }^{b}$ State Key Laboratory Breeding Base of Coal Science and Technology Co-founded by Shanxi Province and the Ministry of Science and Technology, \\ Taiyuan University of Technology, Taiyuan 030024, China \\ ${ }^{\mathrm{c}}$ Research Center for Eco-Environmental Sciences, Chinese Academy of Sciences, Beijing 100085, China
}

\section{H I G H L I G H T S}

- SND was observed in a multi-channel OD at very low DO of 0.10-0.25 $\mathrm{mg} \mathrm{L}^{-1}$.

- SND was identified by micro-environment characteristics within tiny flocs.

- The highest SND occupied $44.1 \%$ of influent nitrogen mass by NMB analysis.

- The maximum SND efficiency was $79 \%$ with SND rate of $5.09 \mathrm{mg} \mathrm{L}^{-1} \mathrm{~h}^{-1}$.

\section{A R T I C L E I N F O}

\section{Article history:}

Received 7 November 2013

Received in revised form 29 July 2014

Accepted 31 July 2014

Available online 20 August 2014

\section{Keywords:}

Simultaneous nitrification and

denitrification

Oxidation ditch

Dissolved oxygen

Micro-environment characteristics

Floc size

Nitrogen mass balances

\begin{abstract}
A B S T R A C T
Simultaneous nitrification and denitrification (SND) was evidently observed in a full-scale multi-channel oxidation ditch (OD), especially occurring within the outer channel under microaerophilic conditions. The optimum average dissolved oxygen (DO) concentration for SND was $0.25 \mathrm{mg} \mathrm{L}^{-1}$ with $79 \%$ SND efficiency and $5.09 \mathrm{mg} \mathrm{L}^{-1} \mathrm{~h}^{-1}$ SND rate, leading to $74.9 \%$ overall TN removal efficiency. Small sized flocs consisting of more nitrifying bacteria enhanced nitrification in favor of SND due to less oxygen diffusion limitation inside flocs than larger flocs under micro-aerated conditions. SND was also identified by co-existing of nitrifying and denitrifying bacteria as well as some microaerophilic microorganisms based on molecular biology analysis. Nitrogen mass balances (NMB) quantitatively demonstrated that the highest SND efficiency accounted for $44.1 \%$ of influent nitrogen mass. Above valuable findings might deeply reveal SND as a principal mechanism of nitrogen removal in a multi-channel OD from macro- to micro-scale.
\end{abstract}

(c) 2014 Elsevier B.V. All rights reserved.

\section{Introduction}

Biological nitrogen removal (BNR) processes have been widely used in municipal wastewater treatment plants (WWTPs) due to high-efficiency and low-cost for eliminating nitrogen from domestic wastewater to prevent oxygen depletion and eutrophication in receiving water bodies [1,2]. Traditional BNR process is a two-step reaction to remove total nitrogen $(\mathrm{TN})$ involving aerobic nitrification of ammonia $\left(\mathrm{NH}_{4}^{+}-\mathrm{N}\right)$ to nitrite $\left(\mathrm{NO}_{2}^{-}-\mathrm{N}\right)$ and nitrate $\left(\mathrm{NO}_{3}^{-}-\mathrm{N}\right)$ followed by anoxic denitrification of the $\mathrm{NO}_{x}^{-}-\mathrm{N}$ to nitrogen gas $\left(\mathrm{N}_{2}\right)[3,4]$.

* Corresponding author at: College of Environmental Science and Engineering, Taiyuan University of Technology, Taiyuan 030024, China. Tel./fax: +86 0351 6079557.

E-mail address: zhouxin@tyut.edu.cn (X. Zhou).
An oxidation ditch (OD) is a modified activated sludge treatment system, consisting of a single- or multi-channel configuration within a ring, oval, or horseshoe-shaped basin [5]. Unlike conventional BNR processes, a high internal recycle flow in ODs can subject mixed liquor to alternating spatial aerobic and anoxic zones distinctly created behind and before surface aerators along the single aerated channel by adjusting aeration supply for enhancing nitrogen removal [6]. Hence, compared with other continuous-flow activated-sludge bioreactors, characterization of nitrogen removal in ODs seems to be regarded as simultaneous nitrification and denitrification (SND), suggesting that nitrification and denitrification occur concurrently in a closed-loop channel due to particular spatial inhomogeneity in profiles of flow regime, oxygen transfer and mixing induced by point-aeration devices based on computational fluid dynamics (CFD) simulations [7-10].

Until now, SND phenomenons have already been successfully observed in lab- [11], pilot- [11-14] and even full-scale OD 


\section{Nomenclature}

$\mathrm{N}_{\text {inf }} \quad$ mass of $\mathrm{TN}$ in the system influent $\left(\mathrm{kg} \mathrm{N} \mathrm{d}^{-1}\right)$

$\mathrm{N}_{\text {eff }} \quad$ mass of TN in the system effluent $\left(\mathrm{kg} \mathrm{N} \mathrm{d}^{-1}\right)$

$\mathrm{N}_{\text {was }} \quad$ mass of nitrogen in the waste sludge $\left(\mathrm{kg} \mathrm{N} \mathrm{d}^{-1}\right)$

$\mathrm{N}_{c 1, n i t}$ mass of $\mathrm{NO}_{x}-\mathrm{N}$ produced through nitrification in the outer channel $\left(\mathrm{kg} \mathrm{N} \mathrm{d}^{-1}\right)$

$\mathrm{N}_{c 2 \text {,nit }}$ mass of $\mathrm{NO}_{x}-\mathrm{N}$ produced through nitrification in the middle channel $\left(\mathrm{kg} \mathrm{N} \mathrm{d}^{-1}\right)$

$\mathrm{N}_{c 3, \text { nit }}$ mass of $\mathrm{NO}_{x}-\mathrm{N}$ produced through nitrification in the inner channel $\left(\mathrm{kg} \mathrm{N} \mathrm{d}^{-1}\right)$

$\mathrm{N}_{c 1 \text {,denit }}$ mass of $\mathrm{NO}_{x}-\mathrm{N}$ denitrified in the outer channel $\left(\mathrm{kg} \mathrm{N} \mathrm{d}^{-1}\right)$

$\mathrm{N}_{c 2 \text {,denit }}$ mass of $\mathrm{NO}_{x}-\mathrm{N}$ denitrified in the middle channel $\left(\mathrm{kg} \mathrm{N} \mathrm{d}^{-1}\right)$

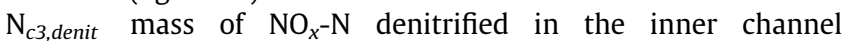
$\left(\mathrm{kg} \mathrm{N} \mathrm{d}^{-1}\right)$

$\mathrm{N}_{\text {unacc }} \quad$ mass of unaccounted nitrogen $\left(\mathrm{kg} \mathrm{N} \mathrm{d}^{-1}\right)$

$Q$ average influent flow rate $\left(10^{4} \mathrm{~m}^{3} \mathrm{~d}^{-1}\right)$ $q \quad$ average waste sludge flow rate $\left(\mathrm{m}^{3} \mathrm{~d}^{-1}\right)$

$r \quad$ returned sludge ratio (\%)

$X_{v} \quad$ MLVSS of the waste sludge $\left(\mathrm{mg} \mathrm{VSS} \mathrm{L}^{-1}\right)$

$f_{N} \quad$ nitrogen fraction of waste sludge $\left(\mathrm{mg} \mathrm{N} \mathrm{mg}^{-1} \mathrm{VSS}\right)$

$\mathrm{NH}_{4}-\mathrm{N}_{\text {inf }} \mathrm{NH}_{4}-\mathrm{N}$ in the influent $\left(\mathrm{mg} \mathrm{L}^{-1}\right)$

$\mathrm{NO}_{x}-\mathrm{N}_{\text {inf }} \mathrm{NO}_{x}-\mathrm{N}$ in the influent $\left(\mathrm{mg} \mathrm{L}^{-1}\right)$

$\mathrm{TN}_{\text {inf }} \quad \mathrm{TN}$ in the influent $\left(\mathrm{mg} \mathrm{L}^{-1}\right)$

$\mathrm{NH}_{4}-\mathrm{N}_{\text {eff }} \mathrm{NH}_{4}-\mathrm{N}$ in the effluent $\left(\mathrm{mg} \mathrm{L}^{-1}\right)$

$\mathrm{NO}_{x}-\mathrm{N}_{\text {eff }} \mathrm{NO}_{x}-\mathrm{N}$ in the effluent $\left(\mathrm{mg} \mathrm{L}^{-1}\right)$

$\mathrm{TN}_{\text {eff }} \quad \mathrm{TN}$ in the effluent $\left(\mathrm{mg} \mathrm{L}^{-1}\right)$

$\mathrm{NH}_{4}-\mathrm{N}_{c 1, \text { out }}$ effluent $\mathrm{NH}_{4}-\mathrm{N}$ from the outer channel $\left(\mathrm{mg} \mathrm{L}^{-1}\right)$

$\mathrm{NH}_{4}-\mathrm{N}_{c 2 \text {,out }}$ effluent $\mathrm{NH}_{4}-\mathrm{N}$ from the middle channel $\left(\mathrm{mg} \mathrm{L}^{-1}\right)$

$\mathrm{NH}_{4}-\mathrm{N}_{c 3, \text { out }}$ effluent $\mathrm{NH}_{4}-\mathrm{N}$ from the inner channel $\left(\mathrm{mg} \mathrm{L}^{-1}\right)$

$\mathrm{NO}_{x}-\mathrm{N}_{c 1, \text { out }}$ effluent $\mathrm{NO}_{x}-\mathrm{N}$ from the outer channel $\left(\mathrm{mg} \mathrm{L}^{-1}\right)$

$\mathrm{NO}_{x}-\mathrm{N}_{c 2, \text { out }}$ effluent $\mathrm{NO}_{x}-\mathrm{N}$ from the middle channel $\left(\mathrm{mg} \mathrm{L}^{-1}\right)$

$\mathrm{NO}_{x}-\mathrm{N}_{c 3, \text { out }}$ effluent $\mathrm{NO}_{x}-\mathrm{N}$ from the outer channel $\left(\mathrm{mg} \mathrm{L}^{-1}\right)$ systems [15-17]. There were some principal explanations or presumptions for nitrogen removal via SND in oxidation ditches: (1) repeatedly swift alternation is between aerobic (after aerators) and anoxic zones (before aerators) of the mixed liquor in the same aerated channel based on inhomogeneous oxygen distribution [18]; (2) low-oxygen nitrification occurs at low sludge loading rate or long HRT and SRT $[14,16,17]$, despite its nitrification rate is generally maximum value at DO of above $2.0 \mathrm{mg} \mathrm{L}^{-1}$; (3) anoxic zones are developed inside the activated-sludge flocs under aerobic conditions [14,19]; (4) novel microbes such as aerobic denitrifiers and nitrifiers adapted to low-oxygen conditions $[16,20]$ are capable of performing SND. Nevertheless, behavior and property of SND in ODs were not deeply understood, especially for micro-environment characteristics related to sludge characteristics and bacterial composition for SND. Furthermore, the potentials of SND in oxidation ditches were not effectively assessed yet.

Therefore, the purposes of the present study were to investigate SND performance under different low-oxygen levels and identify SND by floc size distribution and microbial community structure using fluorescence in situ hybridization (FISH) and polymerase chain reaction-denaturing gradient gel electrophoresis (PCRDGGE) methods. Additionally, SND efficiency was quantitatively evaluated by nitrogen mass balance (NMB) in our OD and also compared in other types of ODs from related studies. We tried to ravel SND as an underlying mechanism of nitrogen removal in a multi-channel OD.

\section{Material and methods}

\subsection{Oxidation ditch system}

A full-scale Orbal OD system with a total volume of $14,916 \mathrm{~m}^{3}$ is located at a municipal WWTP in Beijing, China. It has a capacity of $80,000 \mathrm{~m}^{3} / \mathrm{d}$ and operates in two parallel ditches, each $71.3 \mathrm{~m} \times 65.3 \mathrm{~m} \times 4.5 \mathrm{~m}$ (length $\times$ width $\times$ depth) in size with an effective depth of $4.0 \mathrm{~m}$ and width of $10 \mathrm{~m}$. The OD has a concentric ring-shape consisting of the outer, middle and inner channel and the size ratio of the three channels is approximately 50\%:30\%:20\% (outer:middle:inner). The separate horizontal shafts across the channels possess a number of aeration discs, which provide oxygen to the mixed liquor in the channels and help prevent the activated sludge from settling in Fig. 1. The characteristics of the influent are listed in Table 1.

\subsection{Operational conditions and aeration modes}

During experimental periods, all process parameters except DO concentration were almost identical in the multi-channel system. The temperature of the mixed liquor in the oxidation ditch was $20-25^{\circ} \mathrm{C}$, the mixed liquor suspended solids (MLSS) were 3000 $3500 \mathrm{mg} \mathrm{L}^{-1}$, the returned sludge ratio was $75-100 \%$, the hydraulic retention time (HRT) was between 10 and $12 \mathrm{~h}$, and the sludge retention time (SRT) were controlled between 12 and 14 days during the period. To determine the influences of DO levels across the three aerated channels on SND in a multi-channel oxidation ditch, four types of aeration modes was designed by independently adjusting the number of surface aerators within the each channel or replacing original discs with high-efficient discs from horizontal shafts in the middle and inner channels. Operational conditions and aeration modes are listed in detail in Table 2.

\subsection{SND efficiency and SND rate}

The overall nitrogen removal performance via SND in oxidation ditches was estimated by means of SND efficiency $\left(E_{\mathrm{SND}}\right)$ and SND

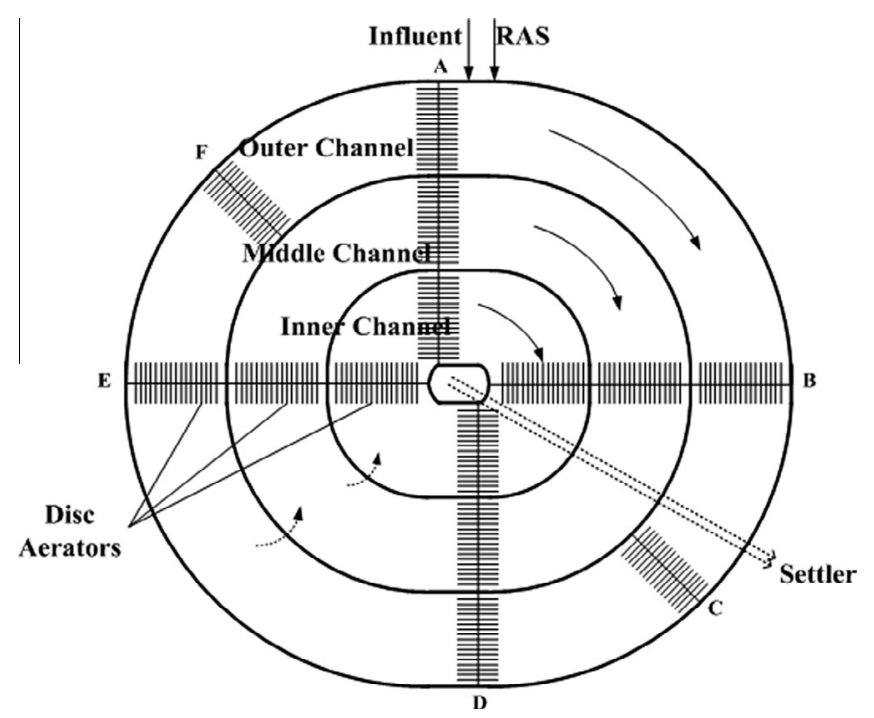

Fig. 1. Schematic diagram of a full-scale multi-channel OD system. 
Table 1

Influent wastewater characteristics. ${ }^{\mathrm{a}}$

\begin{tabular}{|c|c|c|c|c|c|c|}
\hline $\mathrm{pH}$ & $\operatorname{COD}\left(\mathrm{mg} \mathrm{L}^{-1}\right)$ & $\mathrm{BOD}_{5}\left(\mathrm{mg} \mathrm{L}^{-1}\right)$ & $\mathrm{NH}_{4}^{+}-\mathrm{N}\left(\mathrm{mg} \mathrm{L}^{-1}\right)$ & $\mathrm{NO}_{2}^{-}-\mathrm{N}\left(\mathrm{mg} \mathrm{L}^{-1}\right)$ & $\mathrm{NO}_{3}^{-}-\mathrm{N}\left(\mathrm{mg} \mathrm{L}^{-1}\right)$ & $\mathrm{TN}\left(\mathrm{mg} \mathrm{L}^{-1}\right)$ \\
\hline $7.6 \pm 0.3^{b}$ & $383.0 \pm 107.7$ & $176.0 \pm 46.1$ & $44.1 \pm 9.8$ & $0.1 \pm 0.1$ & $0.6 \pm 0.5$ & $57.0 \pm 10.9$ \\
\hline
\end{tabular}

a 83 samples for each wastewater parameter.

b Average \pm standard deviation.

Table 2

List of 16S rRNA gene-targeted oligonucleotide probes used $[23,24]$.

\begin{tabular}{|c|c|c|c|c|}
\hline Probes & Fluorescent label & Sequence $\left(5^{\prime}-3^{\prime}\right)$ & $\mathrm{FA}(\%)^{\mathrm{a}}$ & Specificity \\
\hline Nit3 & FITC & CCTGTGCTCCATGCTCCG & 40 & Nitrobacter spp. \\
\hline Ntspa662 & FITC & GGAATTCCGCGCTCCTCT & 40 & Genus Nitrospira \\
\hline Nrs1156 & FITC & CCCGTTCTCCTGGGCAGT & 30 & Genus Nitrospira \\
\hline Nso190 & Cy5 & CGATCCCCTGCTTTTCTCC & 55 & Ammonium oxidizing $\beta$-proteobacteria \\
\hline Nso1225 & Cy5 & CGCGATTGTATTACGTGTGA & 35 & Ammonium oxidizing $\beta$-proteobacteria \\
\hline
\end{tabular}

a Formamide concentration.

rate $\left(R_{\mathrm{SND}}\right)$ at low DO concentration. $E_{\mathrm{SND}}$ and $R_{\mathrm{SND}}$ were calculated according to equations as below [21]:

$$
\begin{aligned}
& E_{\mathrm{SND}}(\%)=\left(1-\frac{\mathrm{NO}_{x \text { produced }}^{-}}{\mathrm{NH}_{4}^{+} \text {oxidised }}\right) \times 100 \% \\
& R_{\mathrm{SND}}\left(\mathrm{mg} \mathrm{L}^{-1} \mathrm{~h}^{-1}\right)=\frac{\mathrm{NH}_{4 \text { oxidised }}^{+}-\mathrm{NO}_{x \text { produced }}^{-}}{\text {time }(h)}
\end{aligned}
$$

where, $\mathrm{NO}_{x}^{-}$produced is the sum of nitrites and nitrates produced when ammonium was oxidized; $\mathrm{NH}_{4}^{+}$oxidised is the amount of oxidized ammonium through nitrification; time is the HRT in the single-channel system or HRT of the outer channel in the multichannel systems.

\subsection{Chemical analysis}

COD was analyzed by a Multi-Function Reactor (DR2800, Euro Tech) and portable spectrophotometers (DR2800, Hach). BOD $\mathrm{NH}_{4}^{+}-\mathrm{N} \mathrm{NO}_{3}^{-}-\mathrm{N}, \mathrm{NO}_{2}^{-}-\mathrm{N}, \mathrm{TN}$ and MLSS were analyzed according to Standard Methods [22]. $\mathrm{pH}$ was measured with a $\mathrm{pH}$ meter (WTW Multi340i). DO was measured using a portable DO meter (WTW Oxi340i). As DO distribution was not uniform in a channel or even within the same cross-section, the oxygen concentration in each channel was the average of the measurements from eight different cross-sections and twelve measuring points at four different heights at each cross-section along the ditch [16].

\subsection{Floc size distribution}

Floc size distribution was measured with a laser particle size analyzer (Malvern Mastersizer 2000, UK), which enables the measurement of particles in the range of $20-2000 \mu \mathrm{m}$. The average size of the sludge flocs was given as the mean based on the volume equivalent diameter.

\subsection{FISH analysis}

Activated sludge flocs in the outer channel between Modes 2 and 3 were respectively fixed by $4 \%$ paraformaldehyde at $4{ }^{\circ} \mathrm{C}$ for $12 \mathrm{~h}$ for the FISH experiments. The fixed flocs were washed three times with phosphate-buffered saline ( $\mathrm{pH}$ : 7.2), and suspended in phosphate-buffered saline. $10 \mu \mathrm{l}$ suspension including ASF was spotted on gelatin-coated glass slides in the form of layer. After air-dried, the flocs were consecutively dehydrated in $50 \%, 80 \%$, and $100 \%$ ethanol. A hybridization solution containing $5 \mathrm{ng} / \mu \mathrm{l}$ of probe was applied to the slide. In situ hybridization was performed at $46{ }^{\circ} \mathrm{C}$ for $3 \mathrm{~h}$. Excess probes were washed at $48{ }^{\circ} \mathrm{C}$ for $15 \mathrm{~min}$ with washing buffer. Biomass on the slide was stained with DAPI solution. The images of FISH were captured by confocal lasers scanning microscopy (CLSM) and analyzed with LAS AF Lit software. Lists of oligonucleotide probes applied and respective target bacteria are shown in Table 2.

\subsection{PCR-DGGE analysis}

The isolation of total DNA was accomplished with DNA Autoplate (TanBead, Taiwan) by Automatic Plateform for Magnetic System-16 (TanBead, Taiwan) and DNA bands were observed by $1.0 \%$ agarose gel electrophoresis. F357GC (5'-CGCCCGCCGCGCGCGGCGGGCG GGGCGGGGGCACGGGGGGCCTACGGGAGGCAGCAG-3') and R518 (5'-ATTACCGCGGCTGCTGG-3') were used to amplify the segment of eubacterial 16S rDNA. The PCR amplification reaction was performed using an MJ Research PTC-200 Peltier Thermal Cycler (Bio-Rad, USA) at a final volume of $50 \mu \mathrm{l}$. The reaction mixture contained 20 pmol of both primers, $20 \mu \mathrm{mol}$ of each dNTPs, $5 \mu \mathrm{l}$ of $10 \times$ buffer (TaKaRa, Dalian, China), and 1.25 units of Taq DNA polymerase (TaKaRa, Dalian, China). The temperature cycling conditions were $94^{\circ} \mathrm{C}$ for $3 \mathrm{~min}$, followed by 31 cycles of $94^{\circ} \mathrm{C}$ for $30 \mathrm{~s}, 55^{\circ} \mathrm{C}$ for $30 \mathrm{~s}$, and $72{ }^{\circ} \mathrm{C}$ for $1 \mathrm{~min}$. A final extension at $72^{\circ} \mathrm{C}$ for $10 \mathrm{~min}$ was used. The PCR product generated from each sample was separated on an $8 \%$ acrylamide gel with a linear denaturant gradient increasing from $30 \%$ to $60 \%$ using the Bio-Rad D-GENE System (Bio-Rad, USA). The DGGE was performed using $30 \mu \mathrm{l}$ of the PCR product in $1 \times$ TAE buffer at $60{ }^{\circ} \mathrm{C}$ and $70 \mathrm{~V}$ for $960 \mathrm{~min}$. The resulting gel was visualized with Gel Red (Biotium USA). The digital images were captured by a Fluor-S Multilmager (Bio-Rad, USA) and analyzed with Quantity One Software (Bio-Rad, USA).

\subsection{Sequencing analysis}

Prominent DGGE bands were excised and dissolved in $50 \mu \mathrm{l}$ of Milli-Q water overnight at $4{ }^{\circ} \mathrm{C}$. The target DNA fragments were reamplified using primer set F357/R518 without the GC-clamp, thus obtaining a pure sample for cloning and sequencing. The PCR products were ligated into the pMD18-T vector (TaKaRa, Dalian, China) and transformed in Escherichia coli TOP 10 competent cells following the manufacturer's protocols (Biomed, Beijing, China). Colonies were cultured on LB medium with X-gal, IPTG, Amp. The positive colonies were submitted for sequencing using ABI 3730XL capillary sequencers (Biomed, Beijing, China). Homology searches were conducted using the GenBank server of the National Centre for Bio-technology Information (NCBI) and the 
BLAST algorithm. The partial sequences obtained in this study were submitted to the NCBI database under accession numbers.

\subsection{Nitrogen mass balances}

Fig. 2 shows the multi-channel OD system configuration for the NMB analysis. The mass of nitrogen in the influent leaving in the system is mainly through four fractions [25]: effluent TN, TN of the waste sludge, gaseous nitrogen via denitrification and other unaccounted nitrogen (e.g. ammonia stripping and denitrification from the settler). Therefore, the nitrogen mass balance in Fig. 2 is given by:

$\mathrm{N}_{\text {inf }}=\mathrm{N}_{\text {eff }}+\mathrm{N}_{\text {was }}+\mathrm{N}_{c 1, \text { denit }}+\mathrm{N}_{c 2, \text { denit }}+\mathrm{N}_{c 3 \text {,denit }}+\mathrm{N}_{\text {unacc }}$

The mass of $\mathrm{TN}$ in the influent $\left(\mathrm{N}_{\text {inf }}\right)$ is given by:

$\mathrm{N}_{\text {inf }}=\mathrm{QTN}_{\text {inf }}$

The mass of TN in the effluent $\left(\mathrm{N}_{\text {eff }}\right)$ is given by:

$\mathrm{N}_{\text {eff }}=(Q-q) \mathrm{TN}_{\text {eff }}$

To estimate the mass of $\mathrm{N}$ in the waste sludge $\left(\mathrm{N}_{\text {was }}\right)$, the nitrogen fraction in the sludge $\left(f_{\mathrm{N}}\right)$ must be assumed [25]. WRC suggests a value for $f_{\mathrm{N}}$ of $0.1 \mathrm{mg} \mathrm{N} \mathrm{mg}^{-1}$ VSS over a range of sludge ages [26]. $\mathrm{N}_{\text {was }}$ is calculated from:

$\mathrm{N}_{\text {was }}=q X_{v} f_{\mathrm{N}}$

The mass of $\mathrm{N}$ denitrified in the system is calculated by the mass balance on nitrite/nitrate $\left(\mathrm{NO}_{x}-\mathrm{N}\right)$ [6]. To estimate $\mathrm{NO}_{x}-\mathrm{N}$ produced in the each single channel, it is assumed that elimination of $\mathrm{NH}_{4}^{+}-\mathrm{N}$ is totally converted to $\mathrm{NO}_{x}-\mathrm{N}$ only through nitrification and microbial assimilation of $\mathrm{NH}_{4}^{+}-\mathrm{N}$ is negligible. Therefore, the mass of $\mathrm{NO}_{x}-\mathrm{N}$ denitrified in the outer channel $\left(\mathrm{N}_{c 1, \text { denit }}\right)$ is given by:

$\mathrm{N}_{c 1, \text { nit }}=\mathrm{QNH}_{4}-\mathrm{N}_{\text {inf }}+r Q \mathrm{NH}_{4}-\mathrm{N}_{\text {eff }}-(1+r) Q \mathrm{NH}_{4}-\mathrm{N}_{c 1, \text { out }}$

$\mathrm{N}_{c 1, \text { denit }}=Q \mathrm{NO}_{x}-\mathrm{N}_{\text {inf }}+r Q \mathrm{NO}_{x}-\mathrm{N}_{\text {eff }}-(1+r) Q \mathrm{NO}_{x}-\mathrm{N}_{c 1, \text { out }}+\mathrm{N}_{c 1, \text { nit }}$

Similarly, the mass of $\mathrm{NO}_{x}-\mathrm{N}$ denitrified in the middle $\left(\mathrm{N}_{c 2 \text {,denit }}\right)$ and inner channel $\left(\mathrm{N}_{c 3, \text { denit }}\right)$, respectively, is given by:

$\mathrm{N}_{c 2, \text { nit }}=(1+r) Q\left(\mathrm{NH}_{4}-\mathrm{N}_{c 1, \text { out }}-\mathrm{NH}_{4}-\mathrm{N}_{c 2, \text { out }}\right)$

$\mathrm{N}_{c 2, \text { denit }}=(1+r) Q\left(\mathrm{NO}_{x}-\mathrm{N}_{c 1, \text { out }}-\mathrm{NO}_{x}-\mathrm{N}_{c 2, \text { out }}\right)+\mathrm{N}_{c 2, \text { nit }}$

$\mathrm{N}_{c 3, \text { nit }}=(1+r) Q\left(\mathrm{NH}_{4}-\mathrm{N}_{c 2, \text { out }}-\mathrm{NH}_{4}-\mathrm{N}_{c 3, \text { out }}\right)$

$\mathrm{N}_{c 3, \text { denit }}=(1+r) Q\left(\mathrm{NO}_{x}-\mathrm{N}_{c 2, \text { out }}-\mathrm{NO}_{x}-\mathrm{N}_{c 3, \text { out }}\right)+\mathrm{N}_{c 3, \text { nit }}$

The total mass balance of nitrogen in the system is given by:

$\mathrm{N}$ balance $=\left(\frac{\mathrm{N}_{\text {eff }}+\mathrm{N}_{\text {was }}+\mathrm{N}_{c 1, \text { denit }}+\mathrm{N}_{c 2, \text { denit }}+\mathrm{N}_{c 3, \text { denit }}}{\mathrm{N}_{\text {inf }}}\right) \times 100 \%$

\section{Results and discussion}

\subsection{Observation of SND during nitrogen removal}

Fig. 3a and b depict total removal efficiencies of $\mathrm{NH}_{4}^{+}-\mathrm{N}$ and $\mathrm{TN}$ in OD and Fig. 4 shows the profile of nitrogen concentration along

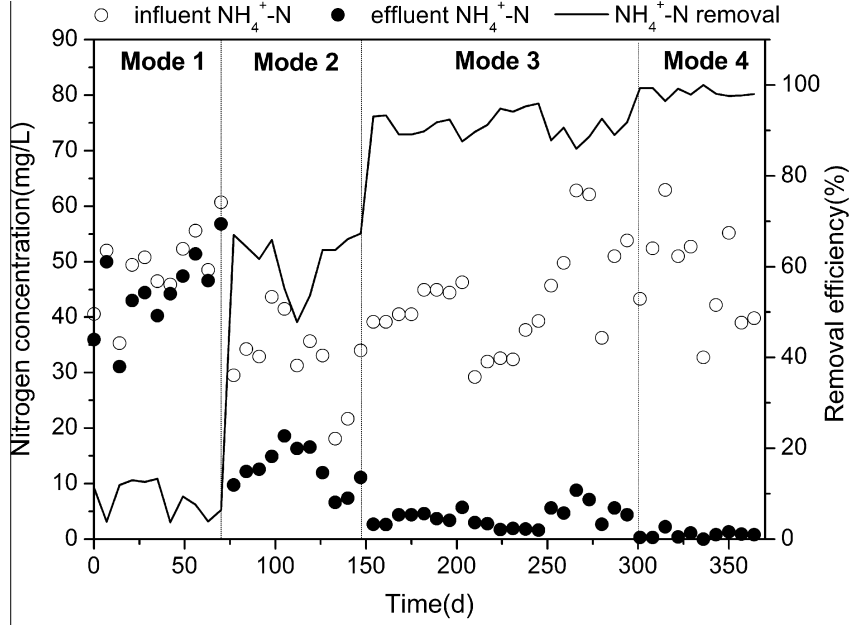

a

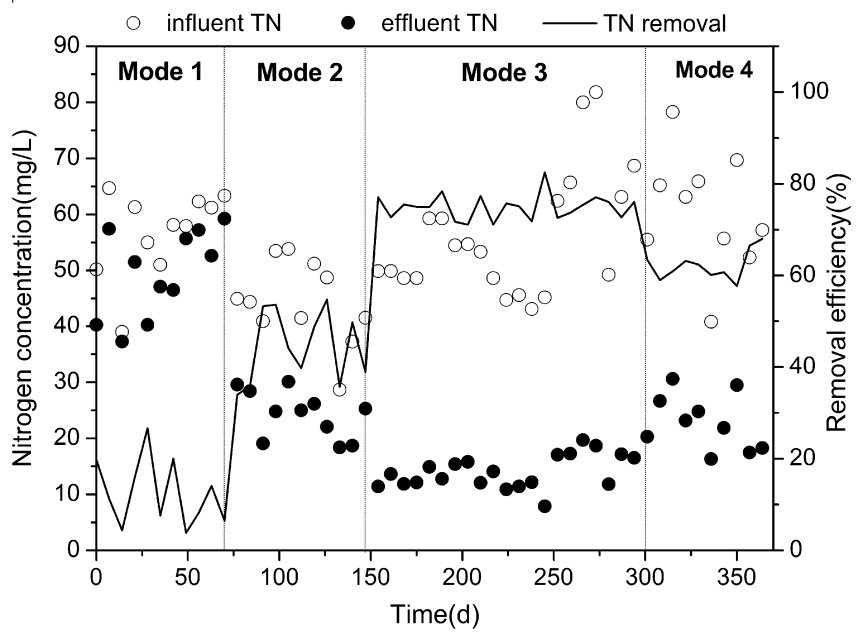

b

Fig. 3. Overall nitrogen removal performances under different aeration modes. (a) Ammonia nitrogen $\left(\mathrm{NH}_{4}^{+}-\mathrm{N}\right)$ removal. (b) Total nitrogen (TN) removal.

the multi-channel OD system under different aeration modes. The effluent ammonia nitrogen concentration was gradually decreased from $44.6 \mathrm{mg} \mathrm{L}^{-1}$ at Mode 1 to $0.8 \mathrm{mg} \mathrm{L}^{-1}$ at Mode 4, corresponding removal efficiency was improved from $8.8 \%$ to almost $100 \%$, implying enhanced nitrification due to significantly increasing oxygen levels in three oxygenated channels. In terms of TN removal, however, the highest efficiency of $74.9 \%$ was achieved at Mode 3 where DO in the outer channel was higher than Modes 2 and 4, but lower than Mode 4 in the remaining two channels (in Table 3). Consequently, overall nitrogen removal capacities were strongly influenced by different aeration strategies based on each channel of the multi-channel OD system. At Mode 1, almost no $\mathrm{NH}_{4}^{+}-\mathrm{N}$ was removed, since nitrification failed to proceed at extremely low DO level of $0.03 \mathrm{mg} \mathrm{L}^{-1}$ in the outer channel, despite DO

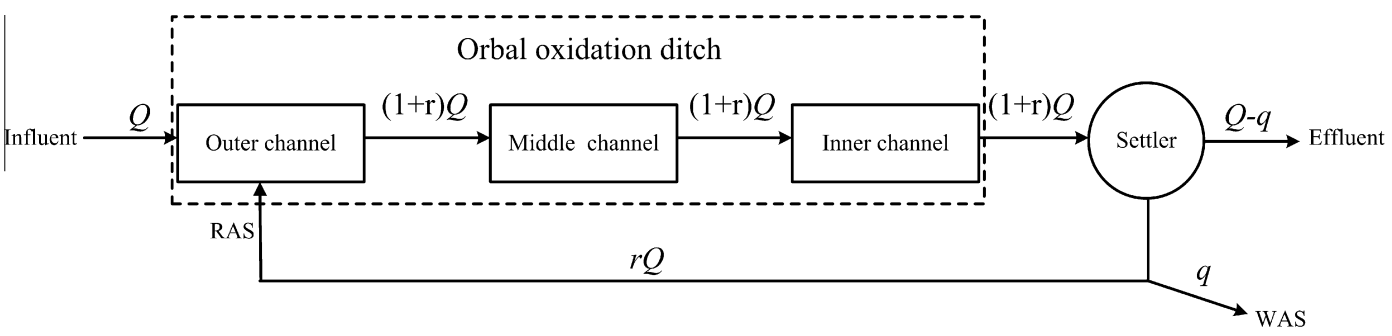

Fig. 2. Schematic diagram showing NMB across the full-scale multi-channel OD system. 

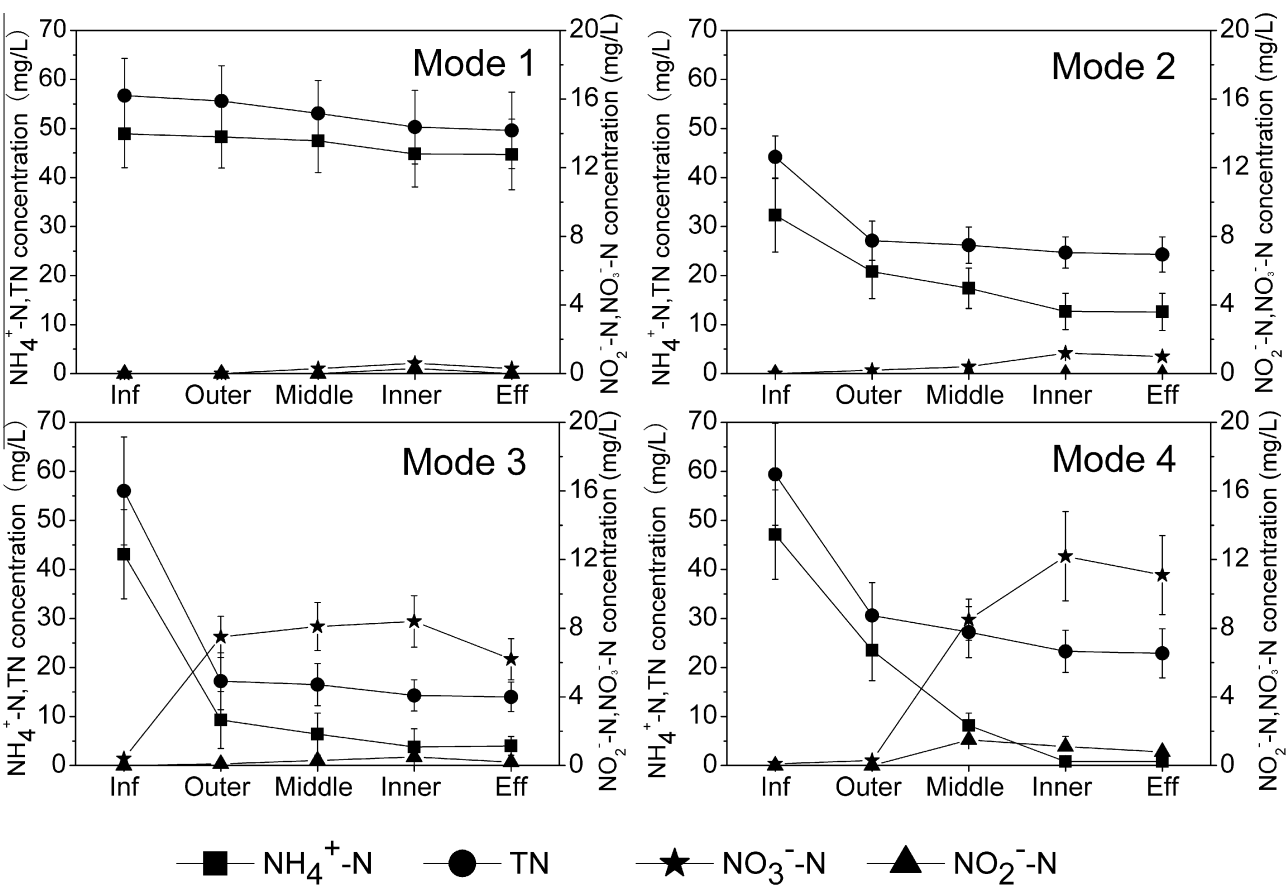

Fig. 4. Transformations of nitrogen-form along the multi-channel OD system under different aeration modes.

Table 3

Aeration modes and operational conditions.

\begin{tabular}{|c|c|c|c|c|}
\hline Operational conditions & Mode 1 & Mode 2 & Mode 3 & Mode 4 \\
\hline Number of aerators (out-middle-inner) & $2-3-3$ & $4-4-4$ & $6-4-4$ & $4-4^{a}-4^{a}$ \\
\hline DO in outer $\left(\mathrm{mg} \mathrm{L}^{-1}\right)$ & $0.03(0-0.06)^{\mathrm{b}}$ & $0.13(0-0.38)^{\mathrm{b}}$ & $0.25(0.03-0.96)^{\mathrm{b}}$ & $0.14(0-0.41)^{\mathrm{b}}$ \\
\hline DO in middle $\left(\mathrm{mg} \mathrm{L}^{-1}\right)$ & 0.14 & 0.35 & 0.46 & 1.47 \\
\hline DO in inner $\left(\mathrm{mg} \mathrm{L}^{-1}\right)$ & 0.76 & 1.05 & 1.41 & 3.10 \\
\hline HRT (h) & 11.90 & 10.80 & 10.50 & 10.10 \\
\hline Operating days $(\mathrm{d})$ & 70 & 77 & 147 & 70 \\
\hline
\end{tabular}

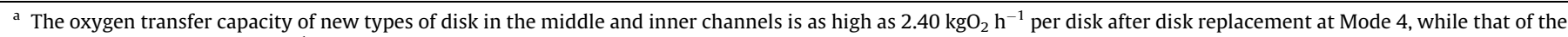
original disk is only $1.04 \mathrm{kgO}_{2} \mathrm{~h}^{-1}$ per disk among other modes.

${ }^{b}$ DO concentrations before aerator and after aerator representing the lowest and highest DO concentrations in the outer channel among the aeration modes.

of $0.76 \mathrm{mg} \mathrm{L}^{-1}$ in the inner channel accounting for only $20 \%$ of the total volume of the oxidation ditch. Although $\mathrm{NH}_{4}^{+}-\mathrm{N}$ were partially removed in the outer channel at Modes 2 and 4 with similarly added oxygen, compared with Mode 2, considerably high DO in the followed two channels at Mode 4 triggered much higher removal efficiencies of $\mathrm{NH}_{4}^{+}-\mathrm{N}$ along with high effluent nitrates which were hardly reduced in Figs. 3 and 4. But at Mode 3, substantial $\mathrm{NH}_{4}^{+}-\mathrm{N}$ was eliminated, accompanying with only a small portion of nitrates in the effluent, suggesting that noticeable TN removal via SND successfully was completed at about $0.20 \mathrm{mg} \mathrm{L}^{-1}$ DO in the outer channel in Fig. 4. It was concluded that such a relatively low DO concentration was sufficient for nitrification, meanwhile, without inhibitory effects on denitrification at the presence of large macroscopical aerated-anoxic environment of the outer channel $[17,27,28]$. According to above results, it was likely that obvious SND was efficiently accomplished at a moderately low level of oxygen supply $[13,16]$ in the outer channel which provided continuous alternation between anoxic and micro-aerobic conditions both in space and time to maintain equally high dynamic balances between nitrification and denitrification rates.

\subsection{Identification of SND by micro-environment characteristics}

Fig. 5 depicts flocs distribution in the outer channel, where remarkable SND was observed, between Modes 2 and 3. Based on the measurement, the average floc diameters were $118 \mu \mathrm{m}$ for
Mode 2 and $69 \mu \mathrm{m}$ for Mode 3, respectively, due to different shear force depended on the number of disc aerators under identical operational parameters. Smaller sludge flocs were clearly observed at Mode 3, which facilitated oxygen mass transfer and reduce oxygen diffusion limitation inside flocs for enhancing nitrification $[29,30]$ under oxygen deficit condition within the outer channel, although its rate lower than the maximum under aerobic conditions, while only incomplete nitrification occurred within the larger flocs in Mode 4 due to the decrease of aerobic micro-zone because excessively low DO failed to penetrated through the centre of the large size particle to supply enough oxygen for nitrifiers. Hence, the characteristics of SND in OD systems under low oxygen condition was quite different from biofilm or aerobic granular sludge processes achieving SND under completely aerobic conditions due to sufficient anoxic zones developed within the inner of much more large-sized biological aggregates [31,32].

The assumption was further supported by the FISH analysis in Fig. 6. It was distinctly that compared with big flocs, the micro flocs in activated sludge consisting of more dispersed nitrifying microorganisms such as ammonia-oxidizing bacteria (AOB) and nitrite-oxidizing bacteria (NOB) could significantly improve denitrification due to less oxygen limitation, once they were exposed to large bulk of aerated-anoxic environment [14,33]. According to PCR-DGGE and sequencing analysis (in Table 4), furthermore, these small sized flocs were also constituted by substantial biomass including uncultured bacterium Bacteroidetes, $\alpha, \varepsilon, \delta$-proteobacteria, 
Table 4

Sequence identities and characteristics of bacterial clones in twenty-three different bands excised from the DGGE gel.

\begin{tabular}{|c|c|c|c|c|}
\hline Band & Closest relatives & Isolation source & Similarity & Group level affiliation \\
\hline 1 & Uncultured Bacteroidetes bacterium Z4MB12 & Wall biomat sample & 99 & Bacteroidetes \\
\hline 2 & Uncultured bacterium F5K2Q4C04IYVXE & Activated sludge & 96 & Uncultured bacterium \\
\hline 3 & Uncultured bacterium ambient_uncontrolled-65 & $\begin{array}{l}\text { Anaerobic fermentation reactor with waste } \\
\text { activated sludge at ambient and } \mathrm{pH} \text { uncontrolled }\end{array}$ & 100 & Bacteroidetes \\
\hline 4 & Uncultured bacterium $\mathrm{K} 1$ & Nitrogen and phosphorus removal bioreactor & 100 & Bacteroidetes \\
\hline 5 & Arcobacter sp. & Lake & 100 & $\varepsilon$-proteobacteria \\
\hline 6 & Uncultured bacterium RBC1-68 & Wastewater treatment plant & 99 & Uncultured bacterium \\
\hline 7 & Denitrifying bacterium enrichment culture NOB_2_G8 & Ebro River Delta sediment & 100 & Denitrifying bacterium \\
\hline 8 & Denitrifying bacterium enrichment culture NOB_3_F2 & Ebro River Delta sediment & 100 & Denitrifying bacterium \\
\hline 9 & Geobacteraceae, IS-22 & Iron(II)-rich seep & 96 & $\delta$-proteobacteria \\
\hline 10 & Chloroflexi, TM7 & Mesophilic anaerobic digester wastewater sludge & 99 & Chloroflexi \\
\hline 11 & Uncultured bacterium SB4-49 & Wastewater treatment plant & 100 & Bacteroidetes \\
\hline 12 & Bacillus sp. & Mangrove soil & 100 & Firmicutes:Bacillus \\
\hline 13 & Uncultured Staphylococcus sp. DH17_95 & Anterior nares & 100 & Firmicutes \\
\hline 14 & Uncultured Staphylococcus sp. VA17_13 & Anterior nares & 100 & Firmicutes \\
\hline 15 & Uncultured alpha proteobacterium & Aerobic activated sludge & 99 & $\alpha$-proteobacterium \\
\hline 16 & Uncultured bacterium F5K2Q4C04ICWOM & Activated sludge & 100 & Uncultured bacterium \\
\hline 17 & Uncultured bacterium clone B144 & Partial nitrifying-ANAMMOX municipal wastewater reactor & 99 & Uncultured bacterium \\
\hline 18 & Uncultured bacterium clone 13 & Denitrification bioreactor & 99 & Uncultured bacterium \\
\hline 19 & Uncultured bacterium clone 13 & Denitrification bioreactor & 98 & Uncultured bacterium \\
\hline 20 & Uncultured eukaryote PR-115 & Activated sludge & 98 & Uncultured eukaryote \\
\hline 21 & Uncultured Bacteroidetes bacterium & Wastewater treatment plant anoxic basin & 100 & Bacteroidetes \\
\hline 22 & Uncultured Firmicutes bacterium TG9 & Cellulolytic bacterial community & 98 & Firmicutes \\
\hline 23 & Uncultured bacterium P1CN04 & Sewage sludge & 97 & Uncultured bacterium \\
\hline
\end{tabular}

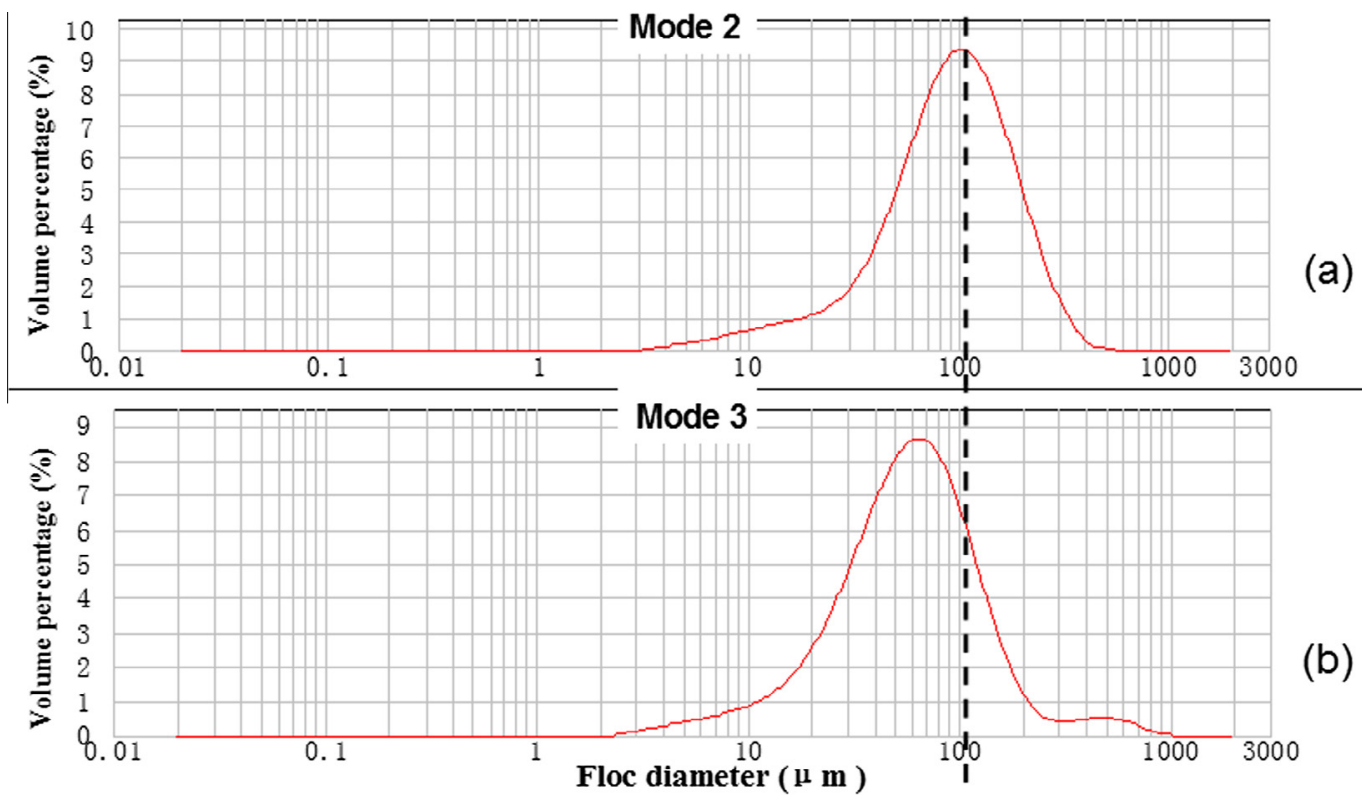

Fig. 5. Floc size distributions in Mode 2 (a) and Mode 3 (b).

Chloroflexi, and Firmicutes, as well as enrichment culture bacterium, indicating the co-existing of aerobic, microaerophilic and denitrifying bacteria performing SND capacity [16]. Therefore, it was essential to properly control of low oxygen level and high shear force by surface aerators using real-time online sensors [34,35] such as $\mathrm{pH}$, DO, ORP and flow velocity to accelerate SND within tiny flocs for enhancing TN removal in the outer channel.

\subsection{Evaluation of SND by nitrogen mass balances}

To evaluate the SND efficiencies responsible for nitrogen removal performance under different aeration patterns, NMB analysis across an entire multi-channel OD system was conducted and the results are summarized in Table 5.
As shown in Table 5 , calculated data presented that perfect $\mathrm{N}$ balances degrees among all modes were achieved at above $90 \%$ according to NMB analysis, demonstrating that unaccounted nitrogen only occupied a small fraction of influent nitrogen mass. The percentages in the total mass of influent nitrogen through the discharge of wasted sludge were ranged 9.8-13.2\%; meanwhile, effluent nitrogen accounted for about $24.5-84.3 \%$ of the influent nitrogen under different aeration modes depending on TN removal efficiency. Therefore, nitrogen leaving from the system was in the form of the gaseous nitrogen mainly through nitrification and denitrification within each single aerated channel. Based on estimated results, although the lost nitrogen in an OD without internal recycling of mixed liquor was attributed by the sum of SND from three channels, the percentages of removed nitrogen mass via SND in the mass of influent nitrogen gradually dropped from the 

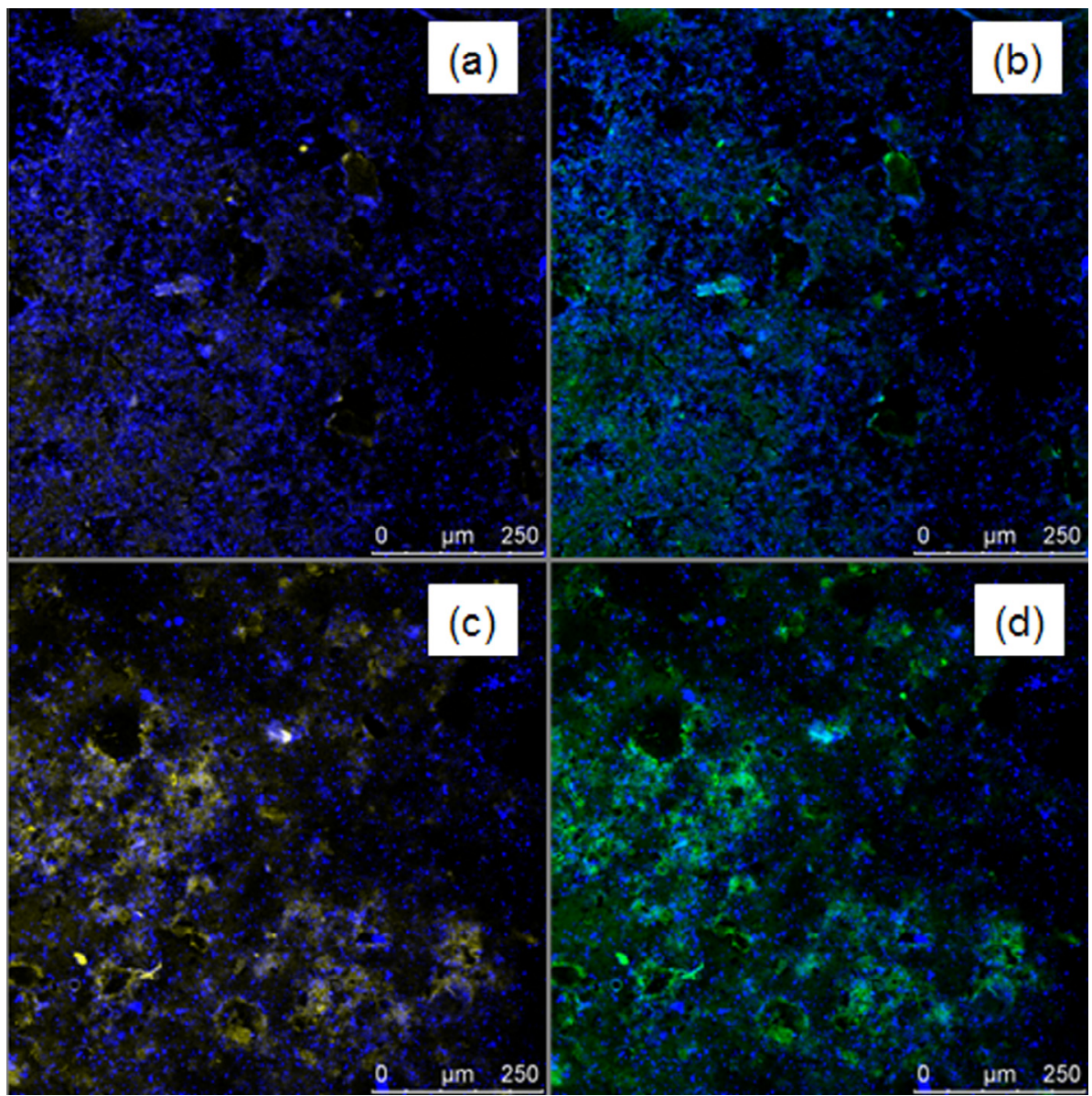

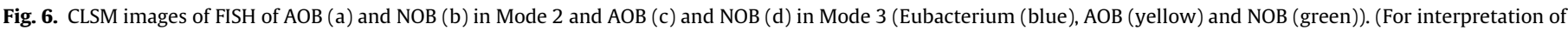
the references to color in this figure legend, the reader is referred to the web version of this article.)

Table 5

Nitrogen mass balances under different aeration modes.

\begin{tabular}{|c|c|c|c|c|c|c|c|c|}
\hline \multirow[t]{2}{*}{ Nitrogen mass } & \multicolumn{2}{|l|}{ Mode 1} & \multicolumn{2}{|l|}{ Mode 2} & \multicolumn{2}{|l|}{ Mode 3} & \multicolumn{2}{|l|}{ Mode 4} \\
\hline & $\mathrm{kg} \mathrm{N} \mathrm{d}^{-1}$ & $\%$ in $\mathrm{N}_{\text {inf }}$ & $\mathrm{kg} \mathrm{N} \mathrm{d}^{-1}$ & $\%$ in $\mathrm{N}_{\text {inf }}$ & $\mathrm{kg} \mathrm{N} \mathrm{d}^{-1}$ & $\%$ in $\mathrm{N}_{\text {inf }}$ & $\mathrm{kg} \mathrm{N} \mathrm{d}^{-1}$ & $\%$ in $\mathrm{N}_{\text {inf }}$ \\
\hline $\mathrm{N}_{\text {inf }}$ & $1814.4(241.3)^{\mathrm{a}}$ & 100.0 & $1458.6(187.1)$ & 100.0 & $1904.0(260.1)$ & 100.0 & 2108.7 (321.3) & 100.0 \\
\hline $\mathrm{N}_{\text {eff }}$ & $1529.3(125.0)$ & 84.3 & $788.5(72.5)$ & 54.1 & $467.3(65.2)$ & 24.5 & $798.3(99.5)$ & 37.9 \\
\hline $\mathrm{N}_{\text {was }}$ & $178.4(22.4)$ & 9.8 & $192.3(37.0)$ & 13.2 & $228.2(31.3)$ & 12.0 & 226.7 (35.7) & 10.8 \\
\hline $\mathrm{N}_{c 1, \text { denit }}$ & $8.3(4.1)$ & 0.5 & $296.1(13.6)$ & 20.3 & $839.4(27.0)$ & 44.1 & $518.8(17.6)$ & 24.6 \\
\hline $\mathrm{N}_{c 2, \text { denit }}$ & $11.6(5.5)$ & 0.6 & $78.0(8.2)$ & 5.3 & $138.8(13.9)$ & 7.3 & $284.4(9.0)$ & 13.5 \\
\hline $\mathrm{N}_{c 3, \text { denit }}$ & $34.9(12.2)$ & 1.9 & $26.0(6.3)$ & 1.8 & $67.3(8.8)$ & 3.5 & $147.0(7.4)$ & 7.0 \\
\hline $\mathrm{N}$ balance & & 97.1 & & 94.7 & & 91.4 & & 93.8 \\
\hline
\end{tabular}

a Values are averages ( \pm standard deviation).

outer to the inner channel at each mode except for Mode 1 due to no nitrification along with little produced $\mathrm{NO}_{x}{ }^{-}-\mathrm{N}$. The largest aerated-anoxic channel optimized by oxygen supply offered a favorable co-existed environment for both nitrifying bacteria adapted to low oxygen and aerobic denitrifiers for promoting SND $[16,20]$, while higher oxygen had an adverse effect on denitrification in the other channels, causing the failure of SND. In the same outer channel, the highest percentage of influent nitrogen mass via SND was achieved at Mode 3 with 44.1\%, about twice as much at Mode 2 or Mode 4. On the other hand, for the same aerated-oxic channels, the ratio of influent nitrogen mass removed via SND at Mode 4 was much higher than two other modes, perhaps because more $\mathrm{NO}_{x}{ }^{-}-\mathrm{N}$ generated under oxygen-rich conditions allowed to be denitrified within scattered anoxic zones established horizontally (in front of surface aerators) and vertically (at the bottom) due to limitation of oxygen transfer $[7,10]$ in the aerobic channels where significant nitrification was accomplished.

\subsection{Comparison and optimization of SND in full-scale plants}

Table 6 summarizes SND performances among different types of oxidation ditches from this study and other related studies. The SND capacity depended on the efficiency and rate of SND occurrence [23], influenced by wastewater characteristics and process parameters $[11,37]$. From Table 6 , the OD systems with very high SND efficiencies (close to 100\%) might have quite slow SND rates due to very long HRTs. For multi-channel ODs, SND efficiencies and SND rates greatly varied from $79 \%$ to $100 \%$ and 0.22 to $5.44 \mathrm{mg} \mathrm{L}^{-1} \mathrm{~h}^{-1}$, respectively. Higher SND rate could accelerate nitrification and denitrification to enhance $\mathrm{TN}$ removal over a 
Table 6

Comparison of SND efficiencies and SND rates among different oxidation ditches.

\begin{tabular}{|c|c|c|c|c|c|c|c|c|c|}
\hline Ditch type & $\begin{array}{l}\text { Organic loading rate } \\
\left(\operatorname{kgCOD~kg}^{-1} \mathrm{MLSS}^{-1} \mathrm{~d}^{-1}\right)\end{array}$ & $\mathrm{DO}\left(\mathrm{mg} \mathrm{L}^{-1}\right)$ & $\mathrm{C} / \mathrm{N}$ & SRT (d) & HRT (h) & $E_{\mathrm{SND}}(\%)$ & $R_{\mathrm{SND}}\left(\mathrm{mg} \mathrm{L}^{-1} \mathrm{~h}^{-1}\right)$ & TN removal (\%) & Refs. \\
\hline Passveer & 0.11 & $0.1-0.5$ & 10 & 44 & 17.2 & 100 & 1.42 & 97.6 & [19] \\
\hline Passveer & 0.04 & $0.1-0.5$ & 12.1 & 164 & 20.5 & 85 & 0.65 & 75.7 & [19] \\
\hline Passveer & $0.02-0.21$ & $>1.0$ & 8.1 & $25-50$ & 60.0 & 65 & 0.54 & $\sim 45$ & [14] \\
\hline Carrousel & $0.20-0.30$ & $1.0-1.2$ & 5.3 & - & 7.9-12 & 67 & $1.61-2.44$ & $60-70$ & [11] \\
\hline Orbal $^{\mathrm{a}}$ & 0.03 & 0.1 & 16.1 & $>50$ & 33.1 & 81 & 1.98 & 76 & [36] \\
\hline Orbal $^{\mathrm{a}}$ & $0.05^{\mathrm{b}}$ & $<0.1$ & $6.8^{\mathrm{c}}$ & 33 & 35.9 & $87-95$ & $0.22-0.24$ & 90.5 & [17] \\
\hline Orbal $^{\mathrm{a}}$ & - & Near 0 & - & $10-30$ & $30-43$ & 100 & $1.06-1.52$ & 87.9 & [20] \\
\hline Orbal $^{\mathrm{a}}$ & 0.06 & 0.1 & 2.7 & - & 16.5 & 91 & 5.44 & 72.1 & [12] \\
\hline Orbal $^{\mathrm{a}}$ & 0.26 & 0.2 & 6.7 & 13 & 10.5 & 79 & 5.09 & 74.9 & This study \\
\hline
\end{tabular}

a The outer channel of Orbal oxidation ditch.

b Organic loading rate based on $\mathrm{BOD}_{5}$.

c $\mathrm{C} / \mathrm{N}$ based on the ratio of $\mathrm{BOD}_{5} / \mathrm{TKN}$.

shorter retention time. The system HRT and rates of nitrification and denitrification under low DO concentrations played significant roles in SND rate. In our study, considerably high SND rate (5.09 $\mathrm{mg} \mathrm{L}^{-1} \mathrm{~h}^{-1}$ ) was obtained, although $79 \%$ of SND efficiency was not very excellent due to adverse impacts of high organic loading and low $\mathrm{C} / \mathrm{N}$ on $\mathrm{TN}$ removal $[11,12,16]$, compared with other OD systems.

To establish effective design criteria for plant optimization and retrofitting aiming at higher nitrogen removal efficiency, SND should be optimum based on premise control of oxygen by aeration adjustment [16] to reach the balance between nitrification and denitrification rates owing to their conflicts of oxygen and carbon substrates [11]. From the above comparisons, for oxidation ditches with higher organic rates and short HRT, enough oxygen intensity and tiny flocs are required for organic oxidation and then nitrification under the low-DO condition without the inhibitory effect on denitrification. For those low-organic loading systems, relatively low DO (below $0.1 \mathrm{mg} \mathrm{L}^{-1}$, even almost zero) should be maintained to prevent over-degradation of carbon substrates and improve denitrification at higher $\mathrm{C} / \mathrm{N}$ ratio, because nitrification is not a limiting factor for those systems with very long HRT and/or SRT.

\section{Conclusions}

Obvious SND occurred at very low DO concentrations between 0.10 and $0.25 \mathrm{mg} \mathrm{L}^{-1}$ in the outer channel of a full-scale multichannel OD system. At average about $0.2 \mathrm{mg} \mathrm{L}^{-1} \mathrm{DO}$ in the outer channel, the highest SND efficiency and SND rate reached $79 \%$ and $5.09 \mathrm{mg} \mathrm{L}^{-1} \mathrm{~h}^{-1}$, respectively. Small sized flocs rather than larger ones consisting of more nitrifying bacteria improved nitrification rate under low oxygen level based on floc size distribution and molecular biology analysis. NMB also quantitatively reveals the highest SND efficiency accounting for $44.1 \%$ of the total influent nitrogen achieved in the outer channel at DO of $0.25 \mathrm{mg} \mathrm{L}^{-1}$. The observations of nitrogen removal and micro-environment characteristics coupled with mass balance analysis demonstrated SND seemed an underlying mechanism of TN removal in a multichannel OD system.

\section{Acknowledgements}

The authors thank Dr. David Howard for the English revision of this manuscript. This work was financially supported by State Key Laboratory Breeding Base of Coal Science and Technology Co-founded by Shanxi Province and the Ministry of Science and Technology, Taiyuan University of Technology (No. MKX201302), the Qualified Personnel Foundation of Taiyuan University of
Technology (QPFT) (No. tyut-rc201262a) and the National Key Technology R\&D Program of China (No. 2006BAC19B02).

\section{References}

[1] Metcalf, Eddy, Wastewater Engineering: Treatment and Reuses, fourth ed. McGraw-Hill, NewYork, 2003.

[2] S.W.H. Van Hulle, H.J.P. Vandeweyer, B.D. Meesschaert, P.A. Vanrolleghem, P. Dejans, A. Dumoulin, Engineering aspects and practical application of autotrophic nitrogen removal from nitrogen rich streams, Chem. Eng. J. 162 (2010) 1-20.

[3] Y.H. Ahn, Sustainable nitrogen elimination biotechnologies: a review, Process Biochem. 41 (2006) 1709-1721.

[4] K. Pynaert, B.F. Smets, D. Beheydt, W. Verstraete, Start-up of autotrophic nitrogen removal reactors via sequential biocatalyst addition, Environ. Sci. Technol. 38 (2004) 1228-1235.

[5] U.S.EPA, Office of Water Washington, D.C. "Wastewater Technology Fact Sheet: Oxidation Ditches". EPA 832-F-00-013, 2000.

[6] X. Chen, T. Fujiwara, K. Nakamachi, Y. Kawaguchi, F. Nishimura, K. Ohtoshi, Evaluation of a novel oxidation ditch system with dual DO control technology for biological nutrient removal by mass balance analysis, Desalination 286 (2012) 24-33.

[7] H.X. Littleton, G.T. Daigger, P.F. Strom, Application of computational fluid dynamics to closed-loop bioreactors: I. Characterization and simulation of fluid-flow pattern and oxygen transfer, Water Environ. Res. 79 (2007) 600612 .

[8] H. Xie, J. Yang, Y. Hu, H. Zhang, Y, Yang, K. Zhang, X. Zhu, Y. Li, C. Yang, Simulation of flow field and sludge settling in a full-scale oxidation ditch by using a two-phase flow CFD model, Chem. Eng. Sci. 109 (2014) 296305.

[9] L. Lei, J. Ni, Three-dimensional three-phase model for simulation of hydrodynamics, oxygen mass transfer, carbon oxidation, nitrification and denitrification in an oxidation ditch, Water Res. 53 (2014) 200-214.

[10] X. Guo, X. Zhou, Q. Chen, J. Liu, Flow field and dissolved oxygen distributions in the outer channel of the Orbal oxidation ditch by monitor and CFD simulation, J. Environ. Sci. 25 (2013) 645-651.

[11] Y. Liu, H. Shi, L. Xia, H. Shi, T. Shen, Z. Wang, G. Wang, Y. Wang, Study of operational conditions of simultaneous nitrification and denitrification in a Carrousel oxidation ditch for domestic wastewater treatment, Bioresour. Technol. 101 (2010) 901-906.

[12] S. Gao, Y. Peng, S. Wang, J. Yan, Novel strategy of nitrogen removal from domestic wastewater using pilot Orbal oxidation ditch, J. Environ. Sci. 18 (2006) 833-839.

[13] X. Zhou, Y. Han, X. Guo, Enhanced total nitrogen removal performance in a modified Orbal oxidation ditch system with internal nitrate recycle, Chem. Eng. J. 228 (2013) 124-131.

[14] X. Hao, H.J. Doddema, J.W. van Groenestijn, Conditions and mechanisms affecting simultaneous nitrification and denitrification in a Pasveer oxidation ditch, Bioresour. Technol. 59 (1997) 207-215.

[15] Y. Liu, H. Shi, Z. Wang, L. Fan, H. Shi, Approach to enhancing nitrogen removal performance with fluctuation of influent in an oxidation ditch system, Chem. Eng. J. 219 (2013) 520-526.

[16] X. Zhou, X. Guo, Y. Han, J. Liu, J. Ren, Y. Wang, Y. Guo, Enhancing nitrogen removal in an Orbal oxidation ditch by optimization of oxygen supply: practice in a full-scale municipal wastewater treatment plant, Bioprocess Biosyst. Eng. 35 (2012) 1097-1105.

[17] G. Daigger, H. Littleton, Characterization of simultaneous nutrient removal in staged, closed-loop bioreactors, Water Environ. Res. 72 (2000) 330-339.

[18] R.J.L.C. Drews, A.M. Greeff, Nitrogen elimination by rapid alternation of aerobic/"anoxic" conditions in "orbal" activated sludge plants, Water Res. 7 (1973) 1183-1194. 
[19] B.E. Rittmann, W.E. Langeland, Simultaneous denitrification with nitrification in single-channel oxidation ditches, J. Water Pollut. Control Fed. (1985) 300308.

[20] H.D. Park, J.M. Regan, D.R. Noguera, Molecular analysis of ammonia-oxidizing bacterial populations in aerated-anoxic Orbal processes, Water Sci. Technol. 46 (2002) 273-280.

[21] K.A. Third, N. Burnett, R. Cord-Ruwisch, Simultaneous nitrification and denitrification using stored substrate (PHB) as the electron donor in an SBR, Biotechnol. Bioeng. 83 (2003) 706-720.

[22] APHA, Standard Methods for the Examination of Water and Wastewater, 20th ed., American Public Health Association/American Water Works Association/ Water Environment Federation, Washington, DC, 1998.

[23] H. Satoh, S. Okabe, Y. Yamaguchi, Y. Watanabe, Evaluation of the impact of bioaugmentation and biostimulation by in situ hybridization and microelectrode, Water Res. 37 (2003) 2206-2216.

[24] A. Gieseke, U. Purkhold, M. Wagner, R. Amann, A. Schramm, Community structure and activity dynamics of nitrifying bacteria in a phosphate-removing biofilm, Appl. Environ. Microbiol. 67 (2001) 1351-1362.

[25] P.S. Barker, P.L. Dold, COD and nitrogen mass balances in activated sludge systems, Water Res. 29 (1995) 633-643.

[26] G. Ekama, Theory, Design and Operation of Nutrient Removal Activated Sludge Processes: A Collaborative Information Document, Water Research Commission, 1984.

[27] K. Pochana, J. Keller, Study of factors affecting simultaneous nitrification and denitrification (SND), Water Sci. Technol. 39 (1999) 61-68.

[28] H. Satoh, Y. Nakamura, H. Ono, S. Okabe, Effect of oxygen concentration on nitrification and denitrification in single activated sludge flocs, Biotechnol Bioeng. 83 (2003) 604-607.
[29] R. Manser, W. Gujer, H. Siegrist, Consequences of mass transfer effects on the kinetics of nitrifiers, Water Res. 39 (2005) 4633-4642.

[30] B. Zhang, K. Yamamoto, S. Ohgaki, N. Kamiko, Floc size distribution and bacterial activities in membrane separation activated sludge processes for small-scale wastewater treatment/reclamation, Water Sci. Technol. 35 (1997) 37-44.

[31] E. Isanta, M.E. Suárez-Ojeda, Á. Val del Río, N. Morales, J. Pérez, J. Carrera, Long term operation of a granular sequencing batch reactor at pilot scale treating a low-strength wastewater, Chem. Eng. J. 198 (2012) 163-170.

[32] Y.-F. Ning, Y.-P. Chen, Y. Shen, N. Zeng, S.-Y. Liu, J.-S. Guo, F. Fang, A new approach for estimating aerobic-anaerobic biofilm structure in wastewater treatment via dissolved oxygen microdistribution, Chem. Eng. J. 255 (2014) 171-177.

[33] D. Li, J. Ganczarczyk, Size distribution of activated sludge flocs, J. Water Pollut. Control Fed. (1991) 806-814.

[34] C. Antileo, H. Medina, C. Bornhardt, C. Muñoz, F. Jaramillo, J. Proal, Actuators monitoring system for real-time control of nitrification-denitrification via nitrite on long term operation, Chem. Eng. J. 223 (2013) 467-478.

[35] P. Martín de la Vega, M. Jaramillo, E Martínez de Salazar Upgrading the biological nutrient removal process in decentralized WWTPs based on the intelligent control of alternating aeration cycles, Chem. Eng. J. 232 (2013) 213220.

[36] C.S. Applegate, B. Wilder, J.R. DeShaw, Total nitrogen removal in a multichannel oxidation system, J. Water Pollut. Control Fed. (1980) 568-577.

[37] J.B. Holman, D.G. Wareham, COD, ammonia and dissolved oxygen time profiles in the simultaneous nitrification/denitrification process, Biochem. Eng. J. 22 (2005) 125-133. 